\title{
Libra and Anxiety Rhetoric: Fear to be Eaten
}

\author{
Jan Veuger* \\ Professor Blockchain Saxion University of Applied Sciences, Netherlands
}

Opinion

ISSN: 2576-8840

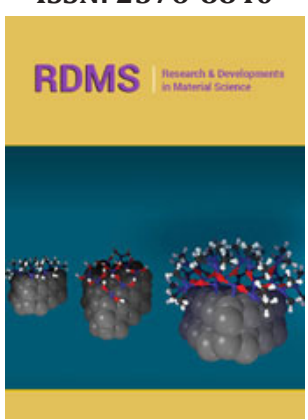

*Corresponding author: Jan Veuger, Professor Blockchain Saxion University of Applied Sciences, Netherlands

Submission: 漹 October 29, 2019

Published: 墭 November 06, 2019

Volume 12 - Issue 2

How to cite this article: Jan Veuger. Libra and Anxiety Rhetoric: Fear to be Eaten. Res Dev Material Sci.12(2).RDMS.000782.2019. DOI: 10.31031/RDMS.2019.12.000782

Copyright@ Jan Veuger, This article is distributed under the terms of the Creative Commons Attribution 4.0 International License, which permits unrestricted use and redistribution provided that the original author and source are credited.

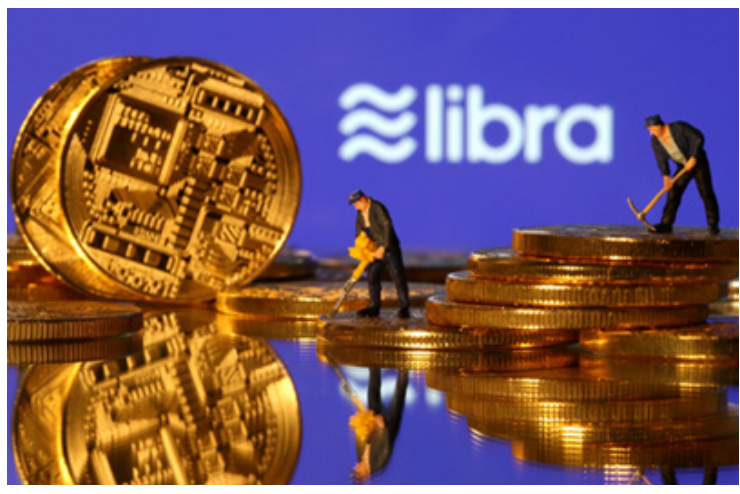

Figure 1: Digital world currency

The libra-project ${ }^{1}$ is a plan for the development of a digital world-coin which should be achieved in 2020 despite some delay ${ }^{2}$. Facebook's idea is that everyone can get access in a simple way and can transfer money with virtually no cost and no bank account being required. The libra could thus become the first digital currency and is comparable to the dollar or euro and can be managed in the Calibra, the digital wallet. Libra wants her digital currency to be linked to the present monetary system, making it more stable than the Bitcoin. The libra works easily by downloading Calibra, available to download on your smartphone, identifying yourself with the libra Association and purchasing libra's using local currencies, after which one can pay others with the libra, provided they have a libra account. The libra is linked to a basket of foreign currencies, securing its stability, which, for example, is not the case for Bitcoin because it is not linked to other currencies. Of importance for the development of the libra is that volume is needed in order to be accepted on a large scale. This can be achieved by the 2.7 billion users of Facebook. Looking only at India, for example, it can be demonstrated that in 2015 there are 155 million users, growing to 310 million users in 2019. It is expected that in 2023 there will be 440 million users and therefore Facebook will have a very large impact on the economy and possibly be a determining factor in it. Facebook, in any case, would like to reach the group of unbanked people ${ }^{3}$.

David Marcus @David Marcus (lead libra Facebook): 'I would caution against reading the fate of libra into this update. Of course, it's not great news in the short term, but in a way it's liberating. Stay tuned for more very soon. Change of this magnitude is hard. You know you're on to something when so much pressure builds up

1 Https://www.rtlz.nl/cryptocurrency/artikel/4778631/libra-zeven-vragen-digitale-munt-crypto-bitcoin-Facebook

2 Another top man behind libra-Dante Disparte-does take the delay into account in the Financial Times. Libra may technically be ready for release next year, he says, but that probably will not apply to the required permits. "This part brings a lot of uncertainty." https://www.ft.com/content/be6a7756eea2-11e9-ad1e-4367d8281195

3 Https://nos.nl/artikel/2293732-waarom-Facebook-zich-opeens-focust-op-mensen-zonder-bankrekening.html

4 Https://nos.nl/artikel/2306761-grote-problemen-voor-Facebooks-digitale-munt-is-de-libra-nog-levensvatbaar.html 


\section{Great resistance}

Libra started with a consortium of 28 companies and organizations and is based in Switzerland. Various parties such as PayPal, Mastercard, eBay, Booking Holdings, Priceline, Visa, and Stripe ${ }^{5}$. Visa and Mastercard have indicated that they will continue to monitor the developments around libra with interest. The libra Association still has several large players as partners, such as Uber and Vodafone. But what is really going on? Countries, institutions and organizations such as China, India, UK, the European Central Bank and the FED worry about the arrival of the libra. They argue that it cannot happen that Facebook just develops financial services without any rules and that it is too dangerous, according to Benoit Coeure of the European Central Bank (ECB). The Bank of China also states that the currency is untenable without the support and supervision of central banks. This is not an unexpected response because China is a centrally managed political system. 'You know you are on the right track if the pressure is so enormous ${ }^{\prime}$, said cofounder of the libra, David Marcus, in response to the criticism and he has a clear point. It is precisely the great potential of libra that explains the great resistance of regulators (Figure 2).

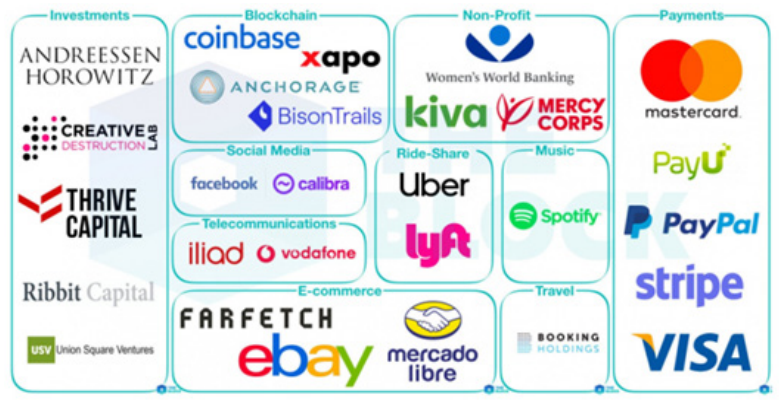

Figure 2: The 28 companies in libra

The benefits of a digital (world-)currency will not be disputed. President Randal Quarles of the Financial Stability Board (FSB) endorses this ${ }^{7}$ in a reaction which he sent to central bankers. The vulnerability to economic shocks as experienced by the current banks can be reduced by digital currencies. The question now is whether a private company like Facebook can manage a currency or if a central bank should do that. The Bank for International Settlements of which the FSB is a subject, has the view that the need for a central bank to develop their own digital money has now become important. A test with public digital money, the E-krona, is already underway in Sweden. The think tank of economists united in the Sustainable Finance Lab ${ }^{8}$, wants The Dutch Central Bank to give citizens direct access to money at the central bank with which the Netherlands can also follow Sweden in its developments towards a public currency. Banks appear to be wary of these developments around the libra. They run the risk of losing revenue because the libra can take over part of the payment traffic, but what else? Underlying is an even greater fear: the growing power of Facebook which is familiar with the digital social and economic life of its users. It can know where its users reside, is familiar with the financial assets of its users and how it is spent. With this information from a commercial company, existing institutions are becoming nervous. But the question is to make a good comparison with the current banks, what they already know about us and the fact that this is not always communicated.

\section{Regulators and banks thwart libra}

Germany, France and Italy are working on measures to prohibit the coming of the libra to Europe. 'The libra is not welcome on European territory. We are taking measures with the Italians and the Germans because our sovereignty is at stake', said the French minister of Finance, Bruno Le Maire ${ }^{9}$. This minister is not in favor of the digital currency ${ }^{10}$ : 'We must refuse the development of the libra in the EU. What is at stake here is the safety of consumers, the stability of the finances within the EU and also the sovereignty of the European states. It is not known what measures are involved. The Netherlands is more reserved than the French, Germans and Italians. Wopke Hoekstra minister of Finance has been in contact with the countries about the digital currency and according to him, the legal consequences must be properly mapped out. 'We are all in favour of innovation in the financial sector. But you have to be very careful about the effects on financial stability ${ }^{11}$.

On October $7^{\text {th }}, 2019$, the BBC $^{12}$ announced conclusions from a G7 report-prepared by representatives of central banks, the IMF and the Financial Stability Board (FSB), a financial stability monitoring body-on certain digital currencies that have the potential to grow very quickly. The representatives see libra as a threat to the current global financial system and, according to them, there are nine major risks to global stable coins: inadequate protection of consumers and investors, fraud and money-laundering sensitivity and privacy issues, and the libra can affect the effectiveness of central banks and seriously affect their monetary (interest) policy. The representatives are of the opinion that Facebook must eliminate these risks while maintaining the restriction of a non-approval by the regulators. The regulators in the Netherlands watch the currency critically. 'We look at the developments with some concerns', ${ }^{13}$ says the supervisor of De Nederlandsche Bank (DNB). 'Regulators and central banks should not want to thwart innovation, but here we see a number of risks. One could think of money laundering, financing of terrorism and the circumvention of sanctions legislation.' The DNB is not yet ready to exclude the libra ${ }^{14}$.

5 Https://www.nrc.nl/nieuws/2019/10/14/Facebookmunt-libra-verder-in-de-verdrukking-a3976713

6 Https://www.nrc.nl/nieuws/2019/10/14/Facebookmunt-libra-verder-in-de-verdrukking-a3976713

7 Https://www.fsb.org/wp-content/uploads/P131019.pdf

8 Https://www.nrc.nl/nieuws/2019/1 0/10/oproep-voor-direct-pinnen-bij-dnb-a3976388

9 Https://www.rtlnieuws.nl/economie/artikel/4889736/libra-maatregelen-Facebook-innovatie-bitcooin

10 Https://newsroom.consilium.europa.eu/events/20190913-eurogroup-meeting-september-2019 


\section{Monetary power to one commercial party}

The loss of key partners within libra does not mean the end of libra ${ }^{15}$. 'Of course, it is no great news in the short term, but in a way, it is liberating' writes libra-co-founder David Marcus ${ }^{16}$ : 'The pressure is enormous (understatement). I respect the decision to wait until there is clarity on the regulation of libra.' Facebook cautions that it is still uncertain which laws and regulations apply to libra, the underlying block chain technology and other crypto currencies. The possible laws and regulations can therefore have a delaying effect on the project and increase the costs whereby new laws and regulations could possibly be designed. But it is not just supervisors, concerns about abuses of power and privacy and possible regulations that may stand in the way of the launch of libra and other digital currencies. The $\mathrm{ECB}^{17}$ calls for additional legislation for tech companies that want to make the step into the financial market. The US Ministry states that digital currencies are used to facilitate illegal conduct and drug trafficking. However, this criticism can also be given of the current monetary system, just as in the Netherlands the DNB is extremely critical of banks and money laundering. Teunis Brosens ${ }^{18}$, an analyst at ING, is also gloomy about the matter. 'I have the feeling that Facebook has taken on too much. They have underestimated how much is involved if you want to launch a global currency.' More importantly, the obvious opposition from the politicians, regulators and monetary world: 'The world is clearly not ready to transfer monetary power to one commercial party.' What is remarkable about this criticism is that the libra, for example, would facilitate criminal behavior with its currency, where apparently such behavior is also taking place at the institutional banks, to this day. In 2019, the Public Prosecutor had to prosecute the ING Bank for facilitating money laundering in addition to the most expensive settlement ever in 2018 for failing supervision regarding money laundering at the ING Bank. The banks now want to jointly check striking transactions in 2019 for money laundering. Interesting in this discussion is that INGboss Ralph Hamers has a clear warning for Mark Zuckerberg: 'If Facebook introduces its digital currency libra without being able to prevent the currency from being used for money laundering, banks cannot do business with Facebook.'19 And warns about this in an interview with the Financial Times ${ }^{20}$. According to him, banks act as a gatekeeper of the financial system. A contradiction with the status of the ING Bank in the Netherlands.

In addition to this file, around sixty percent of the banks are not sufficiently profitable ${ }^{21}$. If the current period of growth turns into a recession, they will have problems ${ }^{22}$. Banks which are not inventive, will be a footnote in history. McKinsey warns ${ }^{23}$ banks of all newcomers to the financial services market. They often have many customer-friendly apps and no old ICT systems. It involves newcomers like Bunq, Revolut, Facebook, Google and Apple. The Netherlands Authority for Consumers \& Markets (ACM) has announced $^{24}$ that it will conduct research into the entry of these companies into the Dutch payment market. ACM sees opportunities because the Dutch market has had little competition for decades, but also risks: Big Techs may be able to use the strong position that they have created in one market to conquer another market.

\section{Conclusion}

\section{Fear to be eaten}

In conclusion, it can be said that the criticism that exists on the libra itself-apart from its connection with Facebook-is no different than criticism that can be stated regarding the dollar or the euro. The dollar or euro also finance things that a government does not like. Nakamoto already stated in 2009 that one must have faith in the current financial system and institutions should not devalue currency, which throughout history has not always been realized. Confidence should also be placed in having sufficient reserves and not creating credit bubbles. The reserves of banks are (very) limited, even after the economic crisis from 2008 onwards and the question is whether the conviction of the International Monetary Fund that crypto coins such as libra should be linked to the central banks is a valid one, considering their reputation in the past decades. Nakamoto (2009) has the following statement: The root problem with conventional currency is all the trust that's required to make it work. The central bank must be trusted not to debase the currency, but the history of fiat currencies is full or breaches of that trust. Banks must be trusted to hold our money and transfer it electronically, but they lend it out in waves of credit bubbles with barely a fraction in reserve. ${ }^{25}$

11 Https://www.rtlnieuws.nl/economie/artikel/4889736/libra-maatregelen-Facebook-innovatie-bitcooin

12 Https://www.bbc.com/news/business-50037223

13 Https://nos.nl/artikel/2306761-grote-problemen-voor-Facebooks-digitale-munt-is-de-libra-nog-levensvatbaar.html

14 Https://nos.nl/artikel/2306761-grote-problemen-voor-Facebooks-digitale-munt-is-de-libra-nog-levensvatbaar.html

15 Https://www.nrc.nl/nieuws/2019/10/11/cryptomunt-libra-verliest-belangrijke-partners-a3976543

16 Https://www.nrc.nl/nieuws/2019/10/11/cryptomunt-libra-verliest-belangrijke-partners-a3976543

17 Https://www.rtlz.nl/tech/artikel/4797926/Facebook-libra-calibra-onzekerheid-cryptocurrency-2020-sec-beurswaakhond

18 Https://www.volkskrant.nl/wetenschap/Facebooks-cryptomunt-libra-op-sterven-na-dood bf18a90e/?utm_campaign=shared_earned\&utm_ medium=social\&utm_source=email

19 Https://www.rtlz.nl/tech/artikel/4893111/facebook-libra-ban-banken-crypto-ing-ralph-hamers

20 Https://www.ft.com/content/df2eb1b2-f3d1-11e9-a79c-bc9acae3b654 


\section{American congress on 23 October about libra: not learned news here}

At October $23^{\text {rd }}$ Mark Zuckerberg respond at the House Financial Services Committee in Capitol Hill. He told the hearing that he understood the reservations about libra but was determined to persevere. I get that I'm not the ideal messenger for this right now. We've faced a lot of issues over the past few years and I'm sure there are a lot of people who wish it were anyone but Facebook that was helping to propose this. He said ${ }^{26}$. But there is a reason we care about this and that's because Facebook is about putting power into people's hands. He said libra was a prime example of American innovation and could help more than a billion adults without a bank account worldwide. He added that Facebook would not control the libra Association and would instead occupy one seat on a governing board of five ${ }^{27}$. The departure of five major financial partners from the project is partly due to political pressure ${ }^{28}$.

Zuckerberg hasn't said anything about whether libra will have transaction fees-a key part of why people like decentralized cryptocurrencies-which don't have them-and a key question for his project which isn't decentralized. In his prepared remarks Zuckerberg also attempted to defuse fears about libra's potential impact on existing currencies. Zuckerberg said libra is not an attempt to create a sovereign currency.' He also noted that libra will be backed mostly by dollars referencing the libra Reserve that will back the coin 1:1. The anticipated makeup of the reserve, beyond Facebook's statements that it will be comprised of governmentbacked currencies and debt instruments, has been unclear, leading lawmakers to fear libra could undermine central banks' ability to carry out monetary policy. Zuckerberg's testimony which lasted more than six hours, may still not have been enough to address the many questions lawmakers have about libra. Near the end of the hearing the committee's ranking member Rep. Patrick McHenry said, 'he is not sure the committee members had learned anything new here. ${ }^{29}$

21 https://www.mckinsey.com/industries/financial-services/our-insights/global-banking-annual-review-2019-the-last-pit-stop-time-for-bold-late-cycle-moves https://www.mckinsey.com/ /media/McKinsey/Industries/Financial\%20Services/Our\%20Insights/Global\%20Banking\%20Annual\%20 Review\%202019\%20The\%20last\%20pit\%20stop\%20Time\%20for\%20bold\%20late\%20cycle\%20moves/McKinsey-Global-Banking-Annual-Review-2019.ashx

22 https://www.nrc.nl/nieuws/2019/10/22/ruim-helft-van-de-banken-niet-goed-voorbereid-op-crisis-a3977650

23 https://www.mckinsey.com/industries/financial-services/our-insights/global-banking-annual-review-2019-the-last-pit-stop-time-for-bold-late-cycle-moves https://www.mckinsey.com/ /media/McKinsey/Industries/Financial\%20Services/Our\%20Insights/Global\%20Banking\%20Annual\%20 Review\%202019\%20The\%20last\%20pit\%20stop\%20Time\%20for\%20bold\%20late\%20cycle\%20moves/McKinsey-Global-Banking-Annual-Review-2019.ashx

24 https://www.acm.nl/nl/publicaties/marktstudie-naar-grote-techbedrijven-op-de-nederlandse-betaalmarkt

25 Bitcoin open source implementation of P2P currency: http://p2pfoundation.ning.com/forum/topics/bitcoin-open-source

26 https://www.bbc.com/news/technology-50152062

27 https://www.bbc.com/news/technology-50152062

28 https://fd.nl/ondernemen/1321324/zuckerberg-libra-moet-vs-beschermen-tegen-chinese-overmacht

29 https://edition.cnn.com/2019/10/23/tech/mark-zuckerberg-facebook-libra-hearing/index.html

For possible submissions Click below:

Submit Article 